\title{
Оптимизация технологии получения молодых коньячных дистиллятов с использованием математического моделирования
}

\author{
Александр Васильевич Васылык, канд. техн. наук, ст. науч. сотр., зам. директора по научной работе, руководитель \\ отделения виноделия, a.v.vasylyk@gmail.com \\ Федеральное государственное бюджетное учреждение науки «Всероссийский национальный научно-исследовательский институт \\ виноградарства и виноделия «Магарач» РАН», Россия, Республика Крым, 298600, г. Ялта, ул. Кирова, 31
}

\begin{abstract}
Приведены основные схемы получения молодых коньячных дистиллятов на аппаратах периодического дейст вия двойной сгонки (шарантского типа), традиционно применяемые в отечественном коньячном производстве и у классических французских производителей. При помощи математического моделирования проведен анализ и определен выход коньячного дистиллята с заданными кондициями и удельные энергетические затраты при одинаковых начальных условиях, но при различных вариантах перегонки. Произведен расчет кондиций основных получаемых продуктов и промежуточных фракций за один цикл дистилляции, а также за длительную последовательность циклов для учета влияния возвращаемых головных и хвостовых фракций, на процесс последующих перегонок. Установлено, что схемы получения кон ьячных дистиллятов, традиционно используемые в странах СНГ, и метод дистилляции MARTELL, явля ются менее эффективными с точки зрения выхода коньячного дистиллята и удельных энергозатрат, чем метод дистилляции коньячных домов REMY MARTIN и HENNESSY. Установлено, что регулирование объемной доли этилового спирта в спирте-сырце коньячном за счет отбора хвостовой фракции при первой перегонке является эффективным способом управления процессом дистилляции, который оказывает влияние на общий выход кондиционного коньячного дистиллята и удельные энергетические затраты. Максимальный выход коньячного дистиллята и минимальные удельные энергозатраты при перегонке виноматериала с объемной долей этилового спирта 10,5 \% и получением коньячного дистиллята с объемной долей этилового спирта $70 \%$ достигаются в случае начала отбора хвостовой фракции при объе м ной доле этилового спирта в парах (спиртовом фонаре) в диапазоне 14-16\%. Показано, что применяе м ые различными производителями схемы получен ия коньячных спиртов имеют потенциал для оптимизации, позволяющий увеличить выход коньячного спирта до 2,4 \% и снизить удельные энергозатраты до 5\%. Оптимизация схемы получения коньячных дистиллятов не требует дополнительных капиталовложений и может служить дополнительным источником прибыли без какой-либо модернизации оборудования.
\end{abstract}

Ключевые слова: коньяк; коньячный дистиллят; шарантский аппарат; двойная сгонка.

\footnotetext{
$\overline{\text { Как цитировать эту статью: }}$

Васылык A.В. Оптимизация технологии получения молодых коньячных дистиллятов с использованием математического моделирования // «Магарач». Виноградарство и виноделие, 2019; 21 (2). C. 162-167. DOI 10.35547/IM.2019.21.2.017

How to cite this article:

Vasylyk A.V. Technology optimization for the production of young brandy distillates based on mathematical modeling // Magarach. Viticulture and Winemaking, 2019; 21(2). - pp. 162167. DOI 10.35547/IM.2019.21.2.017

удК 663.241:66.048.001.57

Поступила 15.05.2019

Принята к публикации 16.05.2019

(C)Авторы, 2019
}

0 R I G I N A L A R T I C L E

\section{Technology optimization for the production of young brandy distillates based on mathematical modeling}

Aleksandr Vasilievich Vasylyk

Federal State Budget Scientific Institution All-Russian National Research Institute of Viticulture and Winemaking Magarach of RAS, 31 Kirova

Street, 298600 Yalta, Republic of Crimea, Russia

The paper describes basic schemes for producing young brandy distillates on double distillation batch machines (charente type) traditionally used in domestic brandy production and by traditional French producers. Mathematical modelling was used to analyze and determine the output of brandy distillate with predetermined parameters and specific energy costs under the same initial conditions, but with different distillation options. We calculated quality parameters of the main resultant products and intermediate fractions during one distillation cycle, as well as during the long cycle sequence to estimate the effect of returned fraction heads and tails on the subsequent distillation process. The analysis established that brandy distillate production schemes traditionally used in the CIS countries and the MARTELL distillation method are less effective in terms of brandy distillate output and specific energy consumption as compared to the REMY MARTIN and HENNESSY cognac distillation method. It was established that control of the volume fraction of ethyl alcohol in the raw brandy alcohol by tail fraction takeoff during the first distillation is an effective way to control the distillation process, which affects the overall output of conditioned brandy distillate and specific energy costs. The maximum brandy distillate output and the minimum specific energy consumption during base wine distillation with volume fraction of ethyl alcohol at $10.5 \%$ and brandy distillate production with volume fraction of ethyl alcohol at $70 \%$ is achieved when the tail fraction takeoff begins with ethyl alcohol volume fraction in pairs (alcohol lamp) within the range of $14-16 \%$. It is demonstrated that production schemes used by various producers to obtain brandy spirits can be optimized, which would increase the output of brandy spirits by $2.4 \%$ and reduce the specific energy costs by $5 \%$. Optimization of the cognac distillates production scheme does not require additional investment, and can serve as an additional profit source without any equipment upgrade.

Key words: brandy; brandy distillate; charente apparatus; double distillation.

$\mathrm{B}$ ведение. Аистимляция вина с цемью получения коньячного АистицАята - оАин из основных процессов коньячного производства, определяющий во многом качество и свойства будущего напитка. К настоящему времени общепризнанной технологией получения спирта Аһя коньяков наивысшего качества является дистимляция на аппаратах Авойной сгонки (шарантского типа). КАассический Аистимляционный аппарат шарантского типа, как правило, состоит из следующих элементов: перегонный куб, дефмегматор, паропровод «мебединая шея», преднагреватель, холодимьник, сборники промежуточных фракций и основных продуктов. Способ нагрева перегонного куба - открытое пцамя газовой горелки. Аля получения 


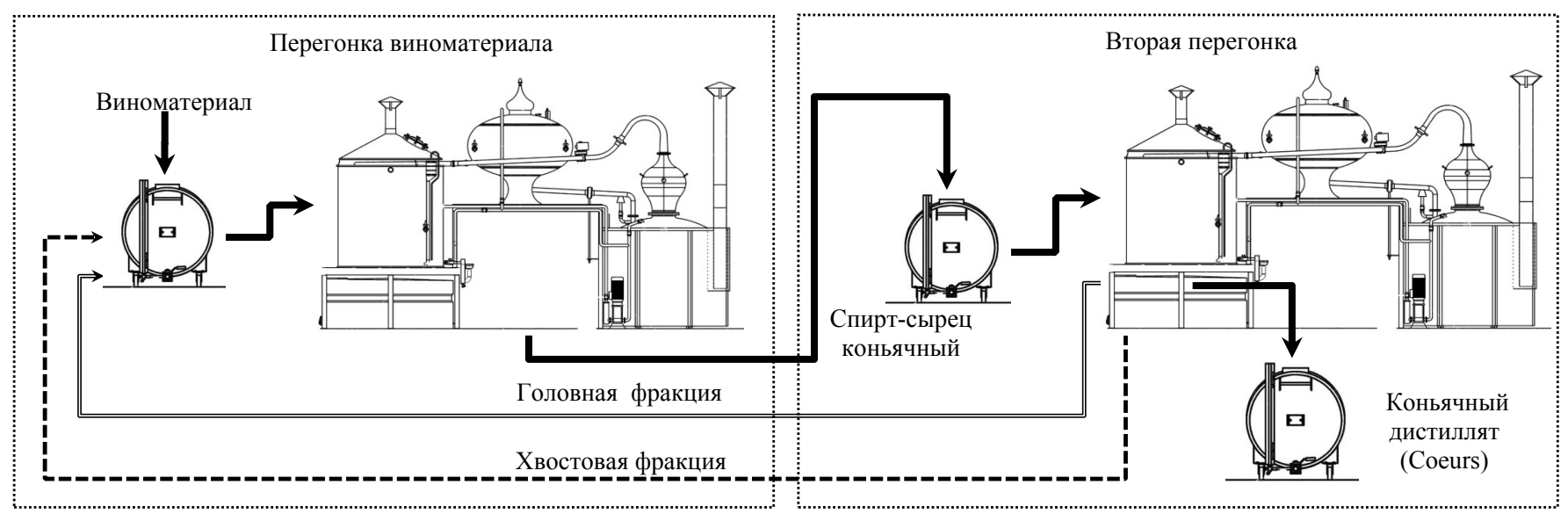

Рис. 1. Схема получения коньячного дистиллята в СНГ (далее по тексту Схема I)

Fig. 1. The scheme for brandy distillate production in the CIS (hereinafter Scheme I)

кондиционного коньячного Аистимяята при применении этих аппаратов необходимо провеАение Авух перегонок: в результате первой получают промежуточный продукт - спирт-сырец коньячный (Brouillis), а при второй - молодой коньячный Аистиццят (Coeurs, Eaux-de-vie), используемый Аля Аальнейшей выдержки [1-4].

Несмотря на кажущуюся простоту процесса, Аанная технология имеет множество вариантов и нюансов, способных оказывать вцияние на состав и качество получаемых продуктов.

Согласно технологии, традиционно применяющейся на территории стран бывшего СССР, наибольшее распространение получима схема, при которой при первой перегонке виноматериала получают спиртсырец коньячный с объемной Аолей спирта около 2832 \% (Аамее по тексту Схема I) [5]. При этом фракционирование Аистимлята, как правимо, не проводят и перегонку заканчивают при показании спиртомера в фонаре (парах Аистиццята) около 0 \% об. Затем, по мере накопмения спирта-сырца коньячного, произвоАят его вторую перегонку с отАелением головной фракции (Ао 3 \% от содержания безводного спирта), коньячного Аистицията с объемной Аолей этилового спирта 62-70\% и хвостовой фракции. Полученный коньячный Аистиццят направцяют на выдержку, а головная и хвостовая фракции возвращаются в исходный виноматериал ими спирт-сырец коньячный (рис. 1).

К недостаткам Аанной схемы можно отнести то, что кондиции получаемых продуктов напрямую зависят от свойств исходного сырья и в процессе Аистимцяции регулирование их состава возможно только в ограниченных предемах.

Во Франции технологические схемы получения коньячных Аистимлятов имеют большее разнообразие, на протяжении Алительного времени сложились схемы, традиционно применяемые разАичными коньячными Аомами, что позволяет получать продукцию, имеющую инАивиАуаАьность и свои специфические свойства.

На рис. 2 изображена схема, известная как метоА MARTELL (Аамее по тексту Схема II). Как виАно, Аанный метод Аостаточно бцизкий к Схеме I. РазАичия закцючаются в Аополнительном отборе головной фракции при первой перегонке виноматериала, а так же вылелении фракции вторичного спирта (Secondes) при второй перегонке (Bonne chauffe), которая по сути анацогична хвостовой фракции, выдемяемой при Схеме I, и возврате головных фракций и вторичного спирта искцючительно в виноматериац, идущий на перегонку.

Аругие известные коньячные Аома, такие как REMY MARTIN и HENNESSY используют бомее сложную схему, преАставленную на рис. 3 (Аалее по

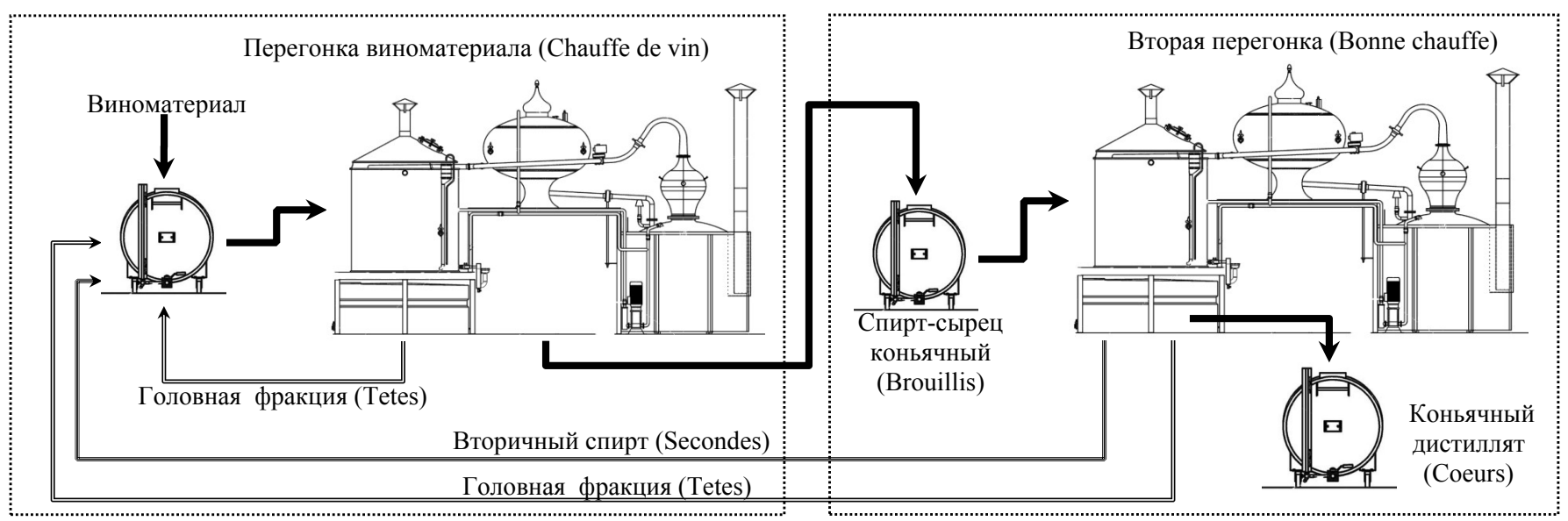

Рис. 2. Схема получения коньячного дистиллята MARTELL (далее по тексту Схема II)

Fig. 2. The MARTELL scheme for brandy distillate production (hereinafter referred to as Scheme II) 


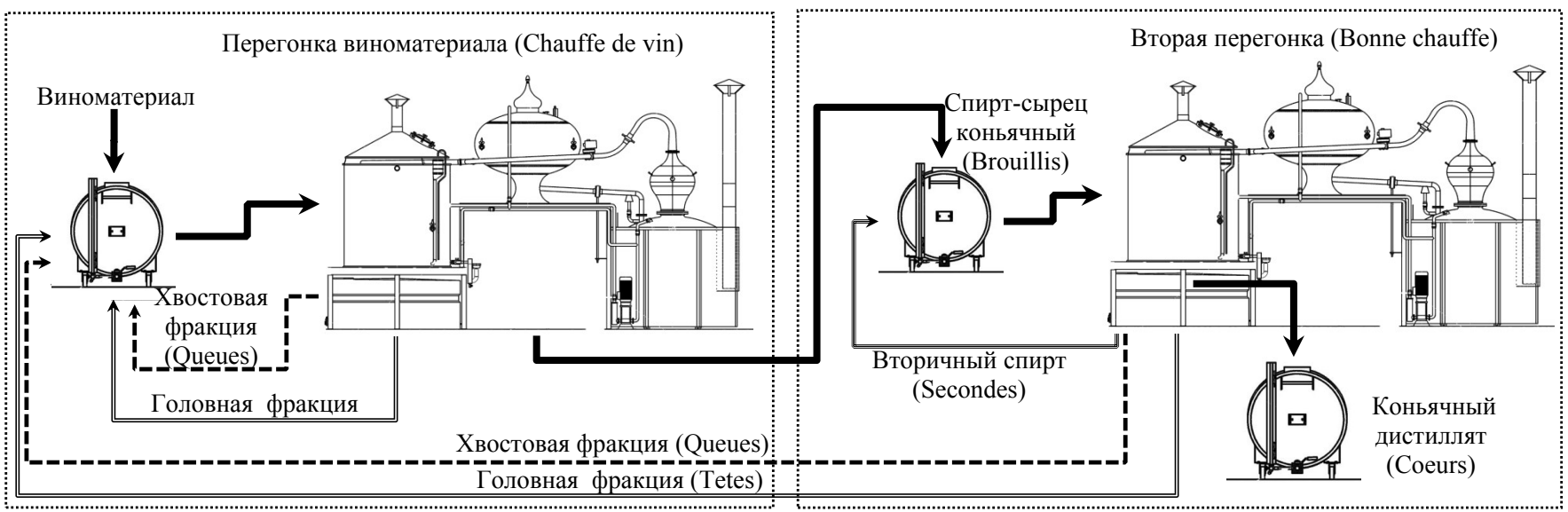

Рис. 3. Схема получения коньячного дистиллята REMY MARTIN, HENNESSY (далее по тексту Схема III)

Fig. 3. The REMY MARTIN, HENNESSY scheme for brandy distillate production (hereinafter referred to as Scheme III).

тексту Схема III), согласно которой при первой перегонке виноматериала производят выАеление как головной фракции (Tetes), так и хвостовой (Queues), которые возвращают в виноматериал послеАующих перегонок. Поцученный спиртсырец коньячный (Brouillis) подвергают второй перегонке, гАе также происходит выдемение головной фракции (Tetes), момОАОго коньячного Аистимцята (Coeurs), «вторичного» спирта (Secondes) и хвостовой фракции (Queues). Головную и хвостовую фракции возвращают в виноматериа , а «вторичный» спирт - в спирт-сырец коньячный.

Использование данной схемы позволяет управлять объемной Аолей этилового спирта в продуктах Аистимляции и в большей степени регулировать процесс ведения Авойной перегонки. При этом фракционирование Аистиццята, то есть момент перехода на отбор следующей фракции, наряду со скоростью ведения процесса, и составцяют основное разАичие в технологии получения коньячных Аистимлятов разАичными производителями. Эти параметры устанавливаются индивидуаАьно и зависят от квалификации и опыта мастера, и качества исходного сырья. Например, при Аистиммяции по метоАY REMY MARTIN при использовании кцассического шарантского аппарата объемом $2500 \wedge$ переход на отбор хвостовой фракции при первой перегонке виноматериала (Chauffe de vin) обычно производят при показании спиртомера в спиртовом фонаре около $5 \%$ об. При второй перегонке (Bonne chauffe) отбор коньячного Аистимяята прекращают при объемной доме этимового спирта в спиртовом фонаре около $59 \%$, затем ведут отбор «вторичного» спирта (Secondes) Ао показаний окомо $8 \%$ об, после чего отбирают хвостовую фракцию Ао окончания дистилмяции (показания в спиртовом фонаре 1-2 \%).

Целью данной работы явмяется при помощи математического моделирования провести сравнение размичных существующих схем получения коньячного спирта и фракционирования дистиццята с точки зрения эффективности по выходу коньячного АистимАята с заданными кондициями и удельных энергетических затрат, и на основании полученных данных оценить возможность оптимизации существующих технологий.

\section{Объекты и методы исследований}

Аля решения данной задачи нами применялся метод математического моделирования перегонки с использованием формул фазового равновесия и простой перегонки [6], который ранее нами бым апробирован и показац достаточно высокую эффективность [7]. Энергозатраты на проведение перегонок рассчитывались на основе тепло-физических характеристик исходных и конечных продуктов дистимляции [8].

Аля моделирования процесса были приняты следующие исходные ус-

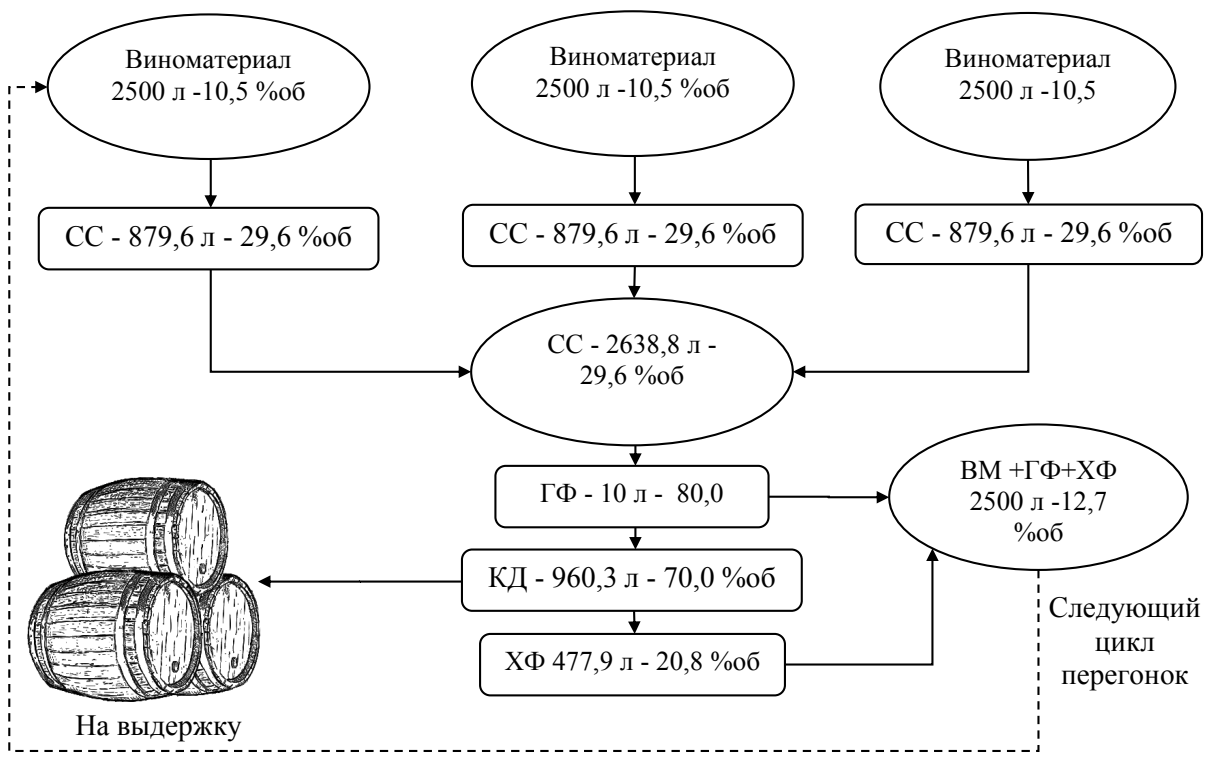

Рис. 4. Схема и кондиции получаемых фракций при двойной перегонке по Схеме I: ВМ-виноматериал; СС - спирт-сырец коньячный; ГФ - головная фракция; КД коньячный дистиллят; ХФ - хвостовая фракция

Fig. 4. The scheme and quality parameters of the resultant fractions obtained after double distillation by Scheme I: BW - base wine; BRS - brandy raw spirit; HF-head fraction; BD brandy distillate; TF - tail fraction 
мовия: объемная Аомя спирта в виноматериаме $10,5 \%$, объемная Аоця этицового спирта в получаемом коньячном Аистимцяте $70 \%$, объем помезной загрузки куба аппарата $2500 \Lambda$.

ОАин цикм перегонок подразумевает 3 перегонки виноматериала (Chauffe de vin) с накопмением спиртасырца коньячного, Аостаточного Аця загрузки в куб, и 1 перегонку спирта-сырца коньячного (Bonne chauffe) c получением кондиционного коньячного АистимАята и промежуточных фракций. Полученные промежуточные продукты возвращаются в перегонный куб и Аополняются свежим виноматериалом

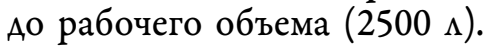
При отборе головной фракции из виноматериала, ее объем принимахся равным $2 \Lambda$, а при выдемении из спирта-сырца коньячного - $10 \Lambda$.

\section{Результаты и обсуждение}

Аля нагмядного преАставАеНИЯ О КОНАИЦИЯХ ИСХОАНОГО сырья, получаемых фракций, их взаимосвязи и вАиянии Аруг на Аруга полученные результаты преАставлены в виде бцок-схем.

Из Аанных, представленных на рис. 4, виАно, что при провеАении АистимАяции по Схеме I объемная домя этимового спирта в спирте-сырце коньячном составцяет типичные $29,6 \%$, а в резумьтате второй перегонки получают гомовную и хвостовую фракции с высоким содержанием этицового спирта, что привоАит к укреплению виноматериаца следующего цикла перегонок.

При анамизе конАиций основных и промежуточных продуктов Аистиццяции по схеме II (рис. 5) виАно, что выделение головной фракции при первой перегонке немного снижает объемную Аолю спирта в спирте-сырце коньячном и, соответственно, повышает ее в виноматериале последующих перегонок Аанного цикма, а выдеменные

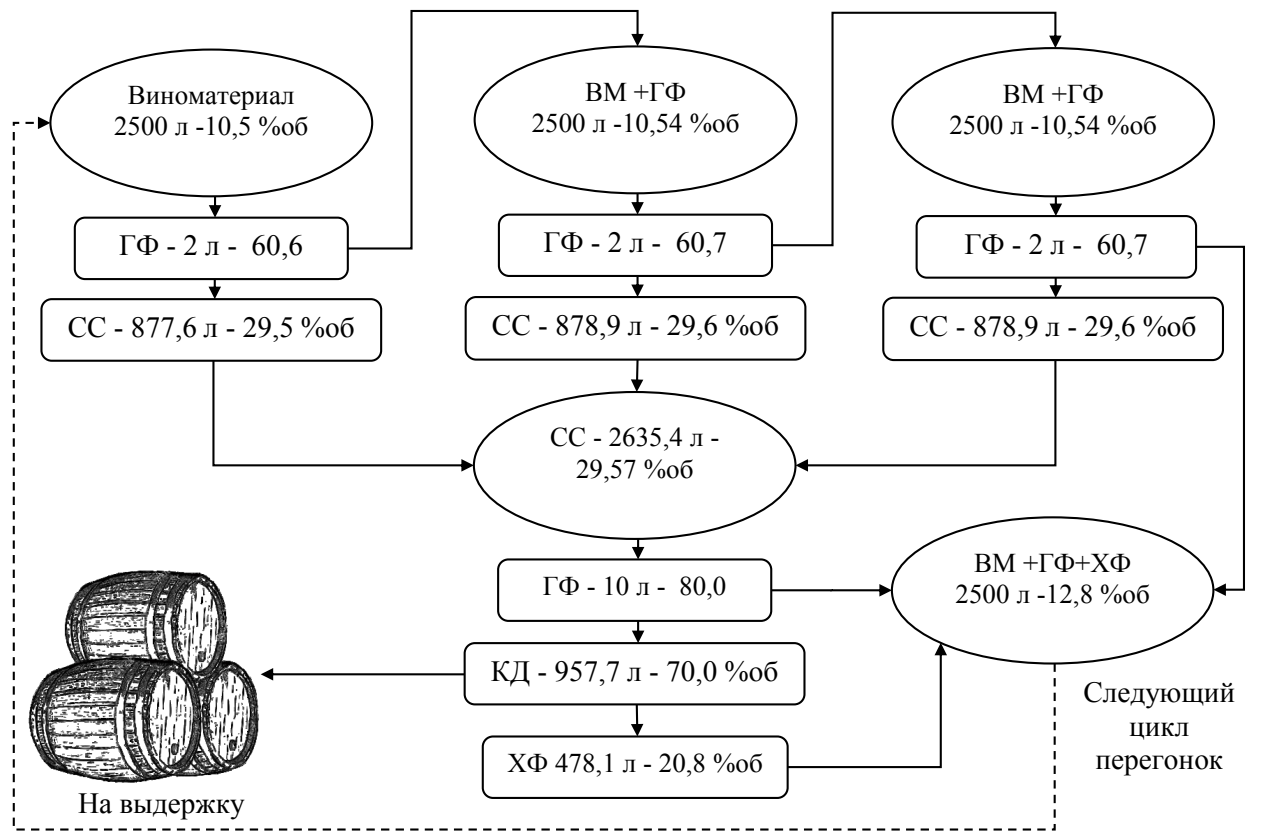

Рис. 5. Схема и кондиции получаемых фракций при двойной перегонке по Схеме II: ВМ-виноматериал; СС - спирт-сырец коньячный; ГФ - головная фракция; КД - коньячный дистиллят; ХФ - хвостовая фракция

Fig. 5. The scheme and quality parameters of the resultant fractions obtained after double distillation by Scheme II: BW - base wine; BRS - brandy raw spirit; HF-head fraction; BD brandy distillate; TF - tail fraction

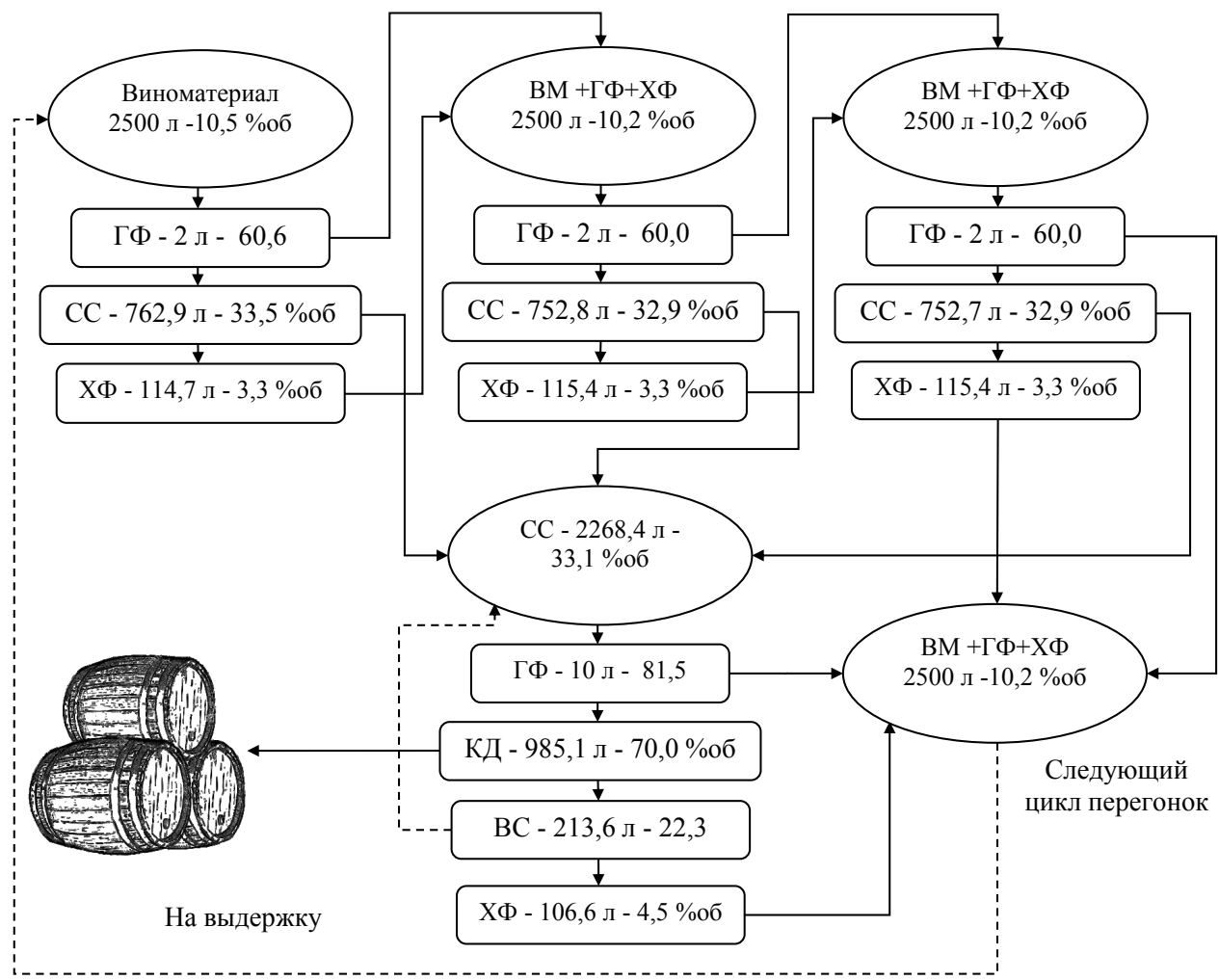

Рис. 6. Схема и кондиции получаемых фракций при двойной перегонке по Схеме III: ВМ-виноматериал; СС - спирт-сырец коньячный; ГФ - головная фракция; КД - коньячный дистиллят; ВС - «Вторичный» спирт; ХФ - хвостовая фракция

Fig. 6. The scheme and quality parameters of the resultant fractions obtained after double distillation by Scheme III: BW - base wine; BRS - brandy raw spirit; HF-head fraction; BD brandy distillate, SS - secondary spirit, TF - tail fraction

головная и хвостовая фракции при второй перегонке способствуют увеличению объемной Аоли спирта в виноматериале следующего цикма.

Анализ данных, представленных на рис. 6, показывает, что отбор хвостовой фракции при перегонке виноматериала по Схеме III, при объемной Аоме спирта в спиртовом фонаре окомо $5 \%$, способствует повышению объемной Аоли спирта в спирте-сырце коньячном Ао 33,1 \% при снижении его объема, 
в сравнении с предыдущими схемами перегонок. В результате второй перегонки выделяется хвостовая фракция с Аовольно низкой объемной Аолей этилового спирта - около 4,5\%, что приводит к снижению объемной Аоли спирта в виноматериаме последующих цикмов Аистимляции.

Обобщив данные, преАставленные на рис. 4-6, можно увидеть, что объем полученного коньячного Аистиццята за 1 цикм в зависимости от схемы и фракционирования может колебаться в значительных пределах - 957-985 ^. ОАнако по одному цикку невозможно оценить реальную эффективность той или иной схемы, поскольку:

- во первых, за счет различного объема возвращаемых фракций количество исходного виноматериала, подвергшегося Аистицмяции, будет разАичным Аһя кажАой схемы;

- во вторых, возвращаемые фракции, в зависимости от схемы, значительно отличаются по объему и по объемной доле этилового спирта $(4,5$ $21 \%)$, что, в свою очереАь, влияет на объем виноматериала и содержание в нем спирта последующих перегонок (разбавмение или укрепкение).

В связи с изможенным, Аця учета указанных факторов нами были проведены расчеты дистилмяций по указанным схемам, которые вкцючали в себя по 4 полных цикма (всего 12 перегонок виноматериала и 4 перегонки спирта-сырца коньячного). При этом определялся удельный выход коньячного Аистицлята, в \% от исходного содержания безводного спирта в виноматериаце, и распреАеление спирта по Аругим фракциям. Кроме этого, рассчитывались энергозатраты по кажАой Аистилмяции и определямись удельные энергозатраты на $1 \Lambda$ получаемого коньячного Аистицията.

Из Аанных, представленных на рис. 7, видно, что наиболее эффективной явмяется Схема III. При этом увеличение выхода коньячного Аистил-

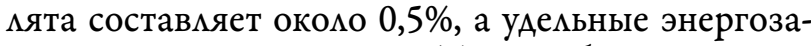
траты снижаются на 3 \%. Таким образом, увеличение объемной доли этимового спирта в спиртесырце коньячном за счет отбора хвостовой фракции при первой перегонке виноматериала хотя и приводит к уменьшению объема спирта-сырца, но в конечном итоге позволяет получить больший выхоА коньячного Аистимлята при второй перегонке.

Как бымо сказано выше, традиционно при перегонке вина по схеме III, французские производители отбор хвостовой фракции начинают осуществлять при концентрации этимового спирта в парах (спиртовом фонаре) окомо $5 \%$ об. В связи с этим, представляет интерес как
будут меняться исследуемы

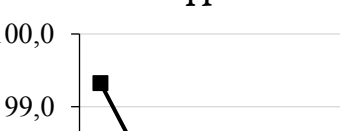

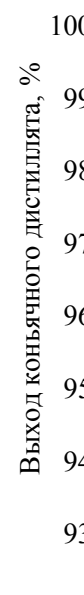
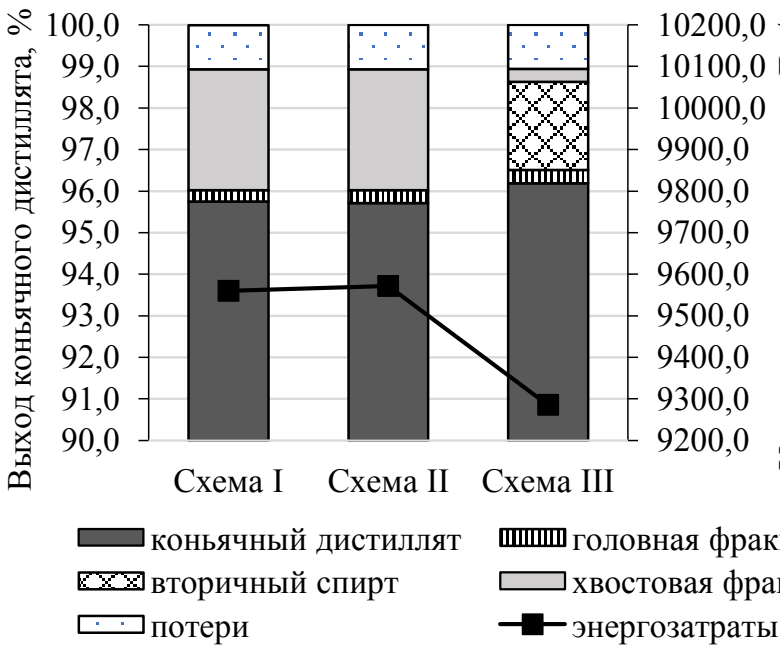

帘

Рис. 7. Распределение безводного спирта по фракциям и удельные энергозатраты при получении коньячных дистиллятов по различным схемам

Fig. 7. Ethanol distribution by fractions and specific energy consumption during brandy distillate production by various schemes

параметры при Аругих условиях отбора хвостовой фракции, например, при увеличении объемной Аоли спирта в фонаре в момент начала отбора и до каких пределов целесообразно увеличивать этот показатель.

Нами был проведен расчет процесса 4 полных цикмов АистимАяции по схеме III, при этом отбор хвостовой фракции осуществлялся в Аиапазоне объемной Аоли этилового спирта в фонаре от 2 до $24 \%$ об. с шагом $1 \%$. Также одновременно производился расчет удемьных энергозатрат.

Как видно из представленных данных на рис. 8, по мере увеличения объемной Аоли спирта в фонаре в момент перехода на отбор хвостовой фракции при перегонке виноматериала, увеличивается выхоА коньячного Аистилмята, вПлоть до концентраций в фонаре 14-18 \% об., а затем начинается постепенное снижение. УАельные энергозатраты также снижаются Ао показаний в фонаре 14-15\% об., а затем снова уве-

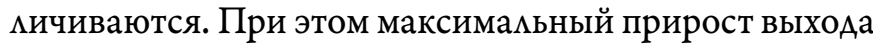
коньячного Аистиццята составцяет около $2,4 \%$, сни-

9600,0

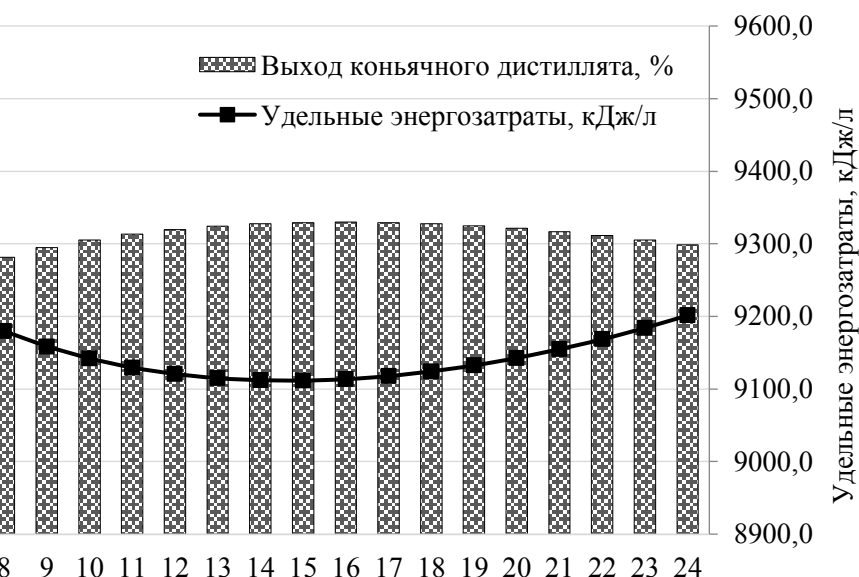

Объемная доля этилового спирта в фонаре, \%

Рис. 8. Взаимосвязь между выходом коньячного дистиллята и удельными энергозатратами в зависимости от параметров отбора хвостовой фракции при дистилляции виноматериала Fig. 8. The relationship between the output of cognac distillate and specific energy consumption depending on the tail fraction takeoff parameters during base wine distillation 
жение энергетических затрат до $5 \%$. Если сравнивать с традиционной Схемой III (начало отбора хвостовой фракции при $5 \%$ об. в фонаре), то выход коньячного Аистилмята увеличивается на $1,1 \%$, а энергозатраты снижаются на $2 \%$. В масштабах предприятия и в цемом отрасли это обеспечивает получение существенной Аополнительной прибыли.

Выводы. В результате проведенных исследований можно сделать вывоА, что с точки зрения выхода коньячного Аистимяята и затрат тепла на перегонку, существующие схемы получения коньячных Аистим^ятов могут быть оптимизированы, что позволит получить экономический эффект без каких-либо капитальных вложений и модернизации оборудования. ОАнако смедует отметить, что при изменении схемы перегонки значительно меняются условия перехода примесей в Аистилмят и распределение их по фракциям [9-14], что в свою очереАь может отразиться на характеристиках конечного продукта - коньячного Аистилмята. В связи с этим, изучение химического состава и качества коньячных дистицяятов, полученных по оптимизированным схемам в реацьных условиях, будет продолжением данной работы.

\section{Источники финансирования}

Работа выполнена в рамках Государственного заАания №0833-2019-0012.

\section{Financing source}

The study was conducted under public assignment №0833-2019-0012.

\section{Конфликт интересов Не заявлен.}

\section{Conflict of interests}

Not declared.

\section{Список литературы / References}

1. Lafon, J., Coulland, P. and Gaybellile, F. (1973a). Le Cognac; Sa Distillation, 5 th ed. J.B. Bailliere (ed.), et Fils, Paris.

2. Dhiman, Anju \& Attri, Surekha. (2011). Production of Brandy. Handbook of Enology:Principles, Practices and Recent Innovations Volume III, Edition: first, Chapter: Production of Brandies, Publisher: Asiatech Publisher, INC. New Delhi, Editors: Prof. V K Joshi, pp.60.

3. La distillation charentaise pour lobtention des eaux-de-vie de cognac // Pays Cognac. - 1993. - № 135. - P. 1, V-XII. - Фp.

4. Leaute, R. (1990). Distillation in Alambic. Am. J. Enol. Vitic., 41: 90.

5. Сборник технологических инструкций, правил и нормативных материалов по винодельческой промышленности / Под ред. Г.Г. Валуйко. М.: Агропромиздат, 1985. 512 с.

Sbomik tekhnologicheskih instruktsiy, pravil i normativny materialov po vinodel'cheskoy proinysblennosti [A collection of standard operation procedures, rules and regulations on wine industry], edited by G.G, Valuyko. M.: Agropromizdat Publ., 1985. 512 p. (in Russian)
6. Фалькович Ю.Е. О некоторых показателях перегонки водно-спиртовых смесей // Труды ВНИИВиВ "Магарач". 1957. Т. 5. С. 43-53.

Fal'kovich Yu.Ye. O nekotorykh pokazatelyakh peregonki vodnospirtovykh smesey // Trudy VNIIViV "Magarach". 1957. Vol. 5. pp. 43-53.

7. Сачаво М.С., Васылык А.В. Усовершенствованная схема получения коньячного спирта на аппаратах двойной сгонки // «Магарач». Виноградарство и виноделие. 2002. № 1. С. 17-21.

Sachavo M.S., Vasylyk A.V. Usovershenstvovannaya skhema polucheniya kon'yachnogo spirta na apparatakh dvoynoy sgonki [An Improved Scheme to Produce Brandy Spirits by Use of Double Distillation Installations]//'Magarach". Vinogradarstvo $i$ vinodelive [Magarach. Viticulture and Winemaking]. 2002. № 1. pp. 17-21. (in Russian).

8. Шейн А.Е. Дистилляционные установки коньячного производства. Исследование процесса и разработка аппаратов. М: Легкая и пищевая промышленность, 1982.57 с.

Sheyn A.Ye. Distillyatsionnyye ustanovki kon'yachnogo proizvodstva. Issledovanive protsessa i razrabotka apparatov. M: Legkaya i pishchevaya promyshlennost', $1982.57 \mathrm{p}$.

9. Скурихин И.М. Химия коньяка и бренди. М.: Дели Принт, 2005. 296 c.

Skurihin I.M. Himiya kon'aka $i$ brendi The chemistry of cognac and brandy production]. M.: Deli Print, 2005. 296 p. (in Russian).

10. Мартыненко Э.Я. Технология коньяка. Симферополь: Таврида, $2003.320 \mathrm{c}$.

Martynenko E.Ya. Tekhnologiva konyaka [Brandy technology]. Simferopol: Tavrida Publ., 2003. 320 p. (in Russian)

11. Малтабар B.М., Ферман Г.И. Технология коньяка. М: Пищевая промышленость, 1971. 344 с

Maltabar V.M., Ferman G.I. Tekhnologiva kon'yaka. M: Pishchevaya promyshlenost', 1971.344 p.

12. Сачаво М.С., Васылык А.В., Простак М.Н. Усовершенствование технологии производства коньячных спиртов с целью одновременного получения коньячных спиртов для ординарных и марочных коньяков // Виноградарство и виноделие: сб. науч. тр. 2005. T. 35. C. 99-101.

SachavoM.S.,VasylykA.V.,ProstakM.N.Usovershenstvovanivetekhnologii proizvodstva kon'yachnykh spirtov s tsel'yu odnovremennogo polucheniva kon'yachnykh spirtov dlya ordinarnykh $i$ marochnykh kon'yakov [An Improved Technology of Cognac Spirit Production With A View Of The Simultaneous Obtaining Of Materials To Be Made into Ordinary And quality Brandies] // Vinogradarstvo $i$ vinodeliye [Viticulture and Winemaking]. 2005. Vol. 35. pp. 99-101 (in Russian).

13. Сачаво М.С., Васылык А.В., Простак М.Н. Рациональное выделение и использование головных фракций при получении коньячных спиртов // «Магарач». Виноградарство и виноделие. 2000. № 4. C. 19-22

Sachavo M.S., Vasylyk A.V., Prostak M.N. Rational Removal And Use Of Heads In View To Produse Brandy Distillaties // "Magarach". Vinogradarstvo i vinodeliye [Magarach. Viticulture and Winemaking]. 2000. № 4. pp. 19-22. (in Russian).

14. Хиабахов Т.С. Основы технологии коньячного производства России. - Новочеркасск, 2001. 159 с.

Hiabahov T.S. Osnovy tekhnologii kon'yachnogo proizvodstva Rossii [The basics of brandy production technology in Russia]. Novocherkassk, 2001. 159 p. (in Russian). 